\title{
Correction to: Teleological epistemology
}

\author{
Jane Friedman ${ }^{1}$
}

Published online: 15 October 2019

(c) Springer Nature B.V. 2019

\section{Correction to: Philos Stud (2019) 176:673-691 https://doi.org/10.1007/s11098-018-1033-7}

In Section 3 of the original version, the Weak Evidentialist Norm is given as follows: 'For every $\mathrm{S}, \mathrm{p}$ and $\mathrm{t}$, S's coming to know $\mathrm{p}$ at $\mathrm{t}$ is permissible'. Unfortunately, this is a (duplicate) statement of the Weak Knowledge Norm.

In fact, the Weak Evidentialist Norm says: 'If one's total evidence clearly and decisively supports $\mathrm{p}$ at $\mathrm{t}$, then believing $\mathrm{p}$ at $\mathrm{t}$ based on that evidence is permissible'.

Publisher's Note Springer Nature remains neutral with regard to jurisdictional claims in published maps and institutional affiliations

The original article can be found online at https://doi.org/10.1007/s11098-018-1033-7.

Jane Friedman

jane.friedman@nyu.edu

1 Department of Philosophy, New York University, New York, NY, USA 